\title{
TINJAUAN YURIDIS TENTANG PELAKSANAAN HAK DAN KEWAJIBAN BADAN PENYELENGGARAAN JAMINAN SOSIAL MENURUT UNDANG-UNDANG NOMOR 24 TAHUN 2011
}

\author{
Marsidah \\ Fakultas Hukum Universitas Palembang \\ Email : marsidahelan@gmail.com
}

\begin{abstract}
The purpose of this study was to determine the rights and obligations of the Social Security Organizing Agency. The type of research used is the type of normative legal research and the data source used is a secondary data source. The rights and obligations of the Social Security Organizing Body are regulated in the provisions of articles 12 and 13 of Law Number 24 of 2011. The right of the Social Security Organizing Body is to obtain operational funds for the operation of programs sourced from social security funds and / or other sources in accordance with statutory provisions -invitation. Whereas the obligation of the Social Security Organizing Body is to provide a single identity number to the participant, that is, a number given specifically by the Social Security Organizing Board to each participant to ensure orderly administration of the rights and obligations of each participant. Information on the performance and financial condition of the Social Security Organizing Agency includes information on the amount of assets and liabilities, receipts and disbursements for each Social Security Fund and / or the total assets and liabilities, receipts and disbursements of the Social Security Organizing Body, providing benefits to all participants in accordance with the Law - Law on the National Social Security System, providing information to participants about the rights and obligations to follow applicable regulations, providing information to participants about the procedure for obtaining rights and fulfilling their obligations, providing information to participants about balances.
\end{abstract}

Keywords: Social Security Organizing Agency

\begin{abstract}
ABSTRAK
Tujuan penelitian ini adalah untuk mengetahui hak dan kewajiban Badan Penyelenggara Jaminan Sosial. Jenis penelitian yang digunakan adalah jenis penelitian hukum normatif dan sumber data yang digunakan adalah sumber data sekunder. Hak dan kewajiban dari Badan Penyelenggara Jaminan Sosial diatur dalam ketentuan pasal 12 dan 13 Undang-Undang Nomor 24 Tahun 2011. Hak Badan Penyelenggara Jaminan Sosial adalah memperoleh dana operasional untuk penyelenggaraan program yang bersumber dari dana jaminan sosial dan/atau sumber lainnya sesuai dengan ketentuan perundang-undangan. Sedangkan kewajiban Badan Penyelenggara Jaminan Sosial adalah memberikan nomor identitas tunggal kepada peserta, yakni nomor yang diberikan secara khusus oleh Badan Penyelenggara Jaminan Sosial kepada setiap peserta untuk menjamin tertib administrasi atas hak dan kewajiban setiap peserta. Informasi mengenai kinerja dan kondisi keuangan Badan Penyelenggara Jaminan Sosial mencakup informasi mengenai jumlah aset dan liabilitas, penerimaan dan pengeluaran untuk setiap Dana Jaminan Sosial dan/atau jumlah aset dan liabilitas, penerimaan dan pengeluaran Badan Penyelenggara Jaminan Sosial, memberikan manfaat kepada seluruh peserta sesuai dengan Undang-Undang tentang Sistem Jaminan Sosial Nasional, memberikan informasi kepada peserta mengenai hak dan kewajiban untuk mengikuti ketentuan yang berlaku, memberikan informasi kepada peserta mengenai prosedur memperoleh hak dan memenuhi kewajibannya, memberikan informasi kepada peserta mengenai saldo.
\end{abstract}

Kata Kunci: Badan Penyelenggara Jaminan Sosial 


\section{PENDAHUluaN}

\section{A. Latar Belakang}

Dunia industri tidak lepas dari peran tenaga kerja dalam hal kelangsungan produksi dalam suatu industri. Tenaga kerja juga merupakan penggerak roda dalam dunia industri. Semakin banyaknya industri yang muncul dan berkembang meruakan titik awal penggunaan tenaga kerja manusia sebagai penggerak roda perekonomian industri. Masalahmasalah timbul, mulai dari upah yang tidak layak, jam kerja, yang tidak manusiawi hingga tenaga kerja anak.

Negara Indonesia sedang giat menarik investor dalam sektor industri untuk menggerakan perekonomian dan diharapkan dapat mengurangi jumlah pengangguran.

Produktivitas tenaga kerja yang tinggi, iklim investasi yang aman serta upah buruh yang murah seringkali menjadi promosi untuk menarik investor asing masuk, akan tetapi dengan terjadinya ketimpanganketimpangan seperti : upah yang tidak layak serta kesehatan dan keselamatan kerja yang buruk, jaminan sosial bagi tenaga kerja dalam melakukan pekerjaannya merupakan kewajiban yang tida dapat ditawar bagi pengusaha sebagai pihak yang mempekerjakan tenaga kerja serta pemerintah dalam kapasitasnya sebagai pengawas dan regulator. Beberapa masalah dalam dunia ketenagakerjaan erat kaitannya dengan jaminan bagi tenaga kerja saat melakukan tugasnya sebagai pekerja.

Untuk itu Pemerintah Indonesia telah menerbitkan Undang-Undang Nomor 24 Tahun 2011 tentang Badan Penyelenggara Jaminan Sosial (BPJS). Sistem jaminan sosial merupakan program negara yang bertujuan memberikan kepastian perlindungan dan kesejahteraan bagi seluruh rakyat.

Berdasarkan hal-hal yang telah diuraikan di atas, maka penulis tertarik untuk meneliti secara lebih lanjut dan menerangkan dalam bentuk tulisan yang berjudul : "TINJAUAN YURIDIS TENTANG PELAKSANAAN HAK DAN KEWAJIBAN

BADAN PENYELENGGARAAN JAMINAN SOSIAL MENURUT UNDANG-UNDANG NOMOR 24 TAHUN 2011".

\section{B. Permasalahan}

Berdasarkan uraian dalam latar belakang di atas, maka permasalahan dalam penelitian ini adalah : Bagaimanakah hak dan kewajiban Badan Penyelenggara Jaminan Sosial menurut Undang-Undang Nomor 24 Tahun 2011?

\section{Tujuan Dan Kegunaan Penelitian}

\section{Tujuan Penelitian}

Tujuan penelitian ini adalah untuk mengetahui sejauhmana hak dan kewajiban Badan Penyelenggara Jaminan Sosial menurut Undang-Undang Nomor 24 Tahun 2011.

\section{Manfaat Penelitian}

Adapun manfaat dalam penelitian ini adalah sebagai sumbangan pemikiran di bidang ilmu pengetahuan hukum khususnya tentang jaminan sosial dan hukum asuransi.

\section{Metode Penelitian}

Menurut Soerjono Soekanto yang dimaksud dengan penelitian hukum adalah kegiatan ilmiah yang didasarkan pada metode sistematika 
dan pemikiran tertentu yang bertujuan untuk mempelajari satu atau segala hukum tertentu dengan jalan menganalisanya. ${ }^{1}$

Penelitian merupakan salah satu cara yang tepat untuk menuntaskan masalah penelitian ini merupakan penelitian hukum normatif dan sumber data pada penelitian ini adalah sumber data sekunder yang diperoleh dari sumber-sumber yang telah ada.

Data sekunder berupa dokumentasi serta sumber tertulis yang bersumber dari buku-buku atau literature yang berkaitan dengan permasalahan dalam penelitian ini. Bahan hukum yang diperoleh di analisis dengan objektif serta menghubungkan dengan pendapat pakar hukum, dan penulis-penulis, kemudian hasilnya ditafsirkan untuk dirumuskan menjadi penemuan dan kesimpulan penelitian.

\section{PEMBAHASAN}

Badan Penyelenggara Jaminan Sosial menjadi harapan bagi masyarakat yang tidak mampu untuk menjadi pelayanan kesehatan apabila harus dirawat di rumah sakit. Hal ini karena biaya kesehatan sangat tinggi.

Definisi Badan Penyelenggara Jaminan Sosial menurut Undang-Undang Nomor 24 Tahun 2011 adalah badan hukum yang dibentuk untuk menyelenggarakan program jaminan sosial. Selanjutnya yang dimaksud jaminan sosial adalah salah satu bentuk perlindungan sosial untuk menjamin seluruh rakyat agar dapat memenuhi kebutuhan hidup yang layak. ${ }^{2}$

\footnotetext{
${ }^{1}$ Ronny Hanintijo Soemitro, Metode Penelitian Hukum dan Juru Metri, Ghalia Indonesia, Jakarta, 1998, hlm. 9

2 Pasal 1 Angka 1 Undang-Undang Nomor 24 Tahun 2011 Tentang BPJS
}

Badan Penyelenggara Jaminan Sosial menyelenggarakan sistem jaminan sosial nasional berdasarkan dengan asas kemanusiaan, manfaat dan keadilan bagi seluruh rakyat Indonesia. ${ }^{3}$ Asas kemanusiaan adalah asas yang terkait dengan penghargaan terhadap martabat manusia. Selanjutnya asas manfaat adalah asas yang bersifat operasional menggambarkan pengelolaan yang efisien dan efektif. kemudian yang dimaksud dengan asas keadilan sosial bagi seluruh rakyat Indonesia adalah asas yang bersifat idiil. Tujuan dari dibentuknya Badan Penyelenggara Jaminan Sosial adalah untuk mewujudkan terselenggaranya pemberian jaminan terpenuhinya kebutuhan dasar hidup yang layak bagi setiap peserta dan/atau anggota keluarganya. Dalam hal ini yang dimaksud dengan kebutuhan dasar hidup adalah kebutuhan esensial setiap orang agar dapat hidup layak, demi terwujudnya kesejahteraan sosial bagi seluruh rakyat Indonesia.

Badan Penyelenggara Jaminan Sosial menyelenggarakan sistem jaminan sosial nasional berdasarkan prinsip : ${ }^{4}$

a. Kegotongroyongan

Yang dimaksud dengan prinsip kegotongroyongan adalah prinsip kebersamaan antar peserta dalam menanggung beban biaya Jaminan Sosial, yang diwujudkan dengan kewajiban setiap peserta membayar iuran sesuai dengan tingkat gaji, upah atau penghasilannya.

b. Nirlaba

Yang dimaksud dengan nirlaba adalah prinsip pengelolaan

\footnotetext{
${ }^{3}$ Pasal 1 Undang-Undang Nomor 24 Tahun 2011 tentang BPJS

${ }^{4}$ Pasal 1 Undang-Undang Nomor 24 Tahun 2011 tentang BPJS
}

Volume 17 Nomor 2. Bulan Mei 2019 
usaha yang mengutamakan penggunaan hasil pengembangan dana untuk memberikan manfaat sebesar-besarnya bagi seluruh peserta.

c. Keterbukaan

Yang dimaksud dengan prinsip keterbukaan adalah prinsip mempermudah akses informasi yang lengkap, benar dan jelas bagi seluruh peserta.

d. Kehati-hatian

Yang dimaksud dengan prinsip kehati-hatian adalah prinsip pengelolaan dana secara cermat, teliti, aman dan tertib.

e. Akuntabilitas

Yang dimaksud dengan prinsip akuntabilitas adalah prinsip pelaksanaan program dan pengelolaan keuangan yang akurat dan dapat dipertanggungjawabkan.

f. Portabilitas

Yang dimaksud dengan portabilitas adalah prinsip memberikan jaminan yang berkelanjutan meskipun peserta berpindah pekerjaan atau tempat tinggal dalam wilayah Negara Kesatuan Republik Indonesia.

g. Kepesertaan Bersifat Wajib

Yang dimaksud dengan prinsip kepesertaan bersifat wajib adalah prinsip yang mengharuskan seluruh penduduk menjadi peserta Jaminan Sosial, yang dilaksanakan secara bertahap.

h. Dana Amanat

Yang dimaksud dengan prinsip dana amanat adalah bahwa iuran dan hasil pengembangannya merupakan dana titipan dari peserta untuk digunakan sebesarbesarnya untuk kepentingan Peserta Jaminan Sosial.

i. Hasil pengelolaan Dana Jaminan Sosial dipergunakan selanjutnya untuk pengembangan program dan untuk sebesar-besar kepentingan peserta.

Dalam Undang-Undang Nomor 24 Tahun 2011 dibentuk Badan Penyelenggara Jaminan Sosial. Badan Penyelenggara Jaminan Sosial dibagi menjadi dua, yaitu : Badan Penyelenggara Jaminan Sosial Kesehatan dan Badan Penyelenggara Jaminan Sosial Ketenagakerjaan. Badan Jaminan Sosial Kesehatan menyelenggarakan program jaminan kesehatan. Sedangkan Badan Penyelenggara Jaminan Sosial Ketenagakerjaan menyelenggarakan program jaminan kecelakaan kerja, jaminan hari tua, jaminan pensiun dan jaminan kematian. Badan Penyelenggara Jaminan Sosial yang dimaksud dalam Undang-Undang Nomor 24 Tahun 2011 berbentuk badan hukum publik dan bertanggung jawab kepada Presiden. Untuk tempat kedudukan Badan Penyelenggara Jaminan Sosial sendiri terletak di Ibukota Negara Republik Indonesia, akan tetapi Badan Penyelenggara Jaminan Sosial juga dapat mempunyai kantor perwakilan di provinsi dan kantor cabang di kabupaten/kota.

\section{Tugas, Wewenang, Hak dan Kewajiban Badan Penyelenggara Jaminan Sosial}

Sebagai lembaga baru yang dibentuk berdasarkan gabungan dari beberapa lembaga yang sudah ada terlebih dahulu, Badan Penyelenggara Jaminan Sosial memiliki tugas, fungsi dan kewajiban yang hampir sama dengan lembaga terdahulu. Dapat 
dikatakan bahwa tugas, wewenang dan kewajiban tersebut merupakan warisan dari lembaga yang sudah ada sebelumnya. Badan Penyelenggara Jaminan Sosial memiliki beberapa tugas dan wewenang. Tugas Badan Penyelenggara Jaminan Sosial adalah :

a. Melakukan dan/atau menerima pendaftaran peserta.

b. Memungut dan mengumpulkan iuran dari peserta dan pemberi kerja.

c. Menerima bantuan iuran dari pemerintah.

d. Mengelola dana jaminan sosial untuk kepentingan peserta.

e. Mengumpulkan dan mengelola data peserta program jaminan sosial.

f. Membayarkan manfaat dan/atau membiayai pelayanan kesehatan sesuai dengan ketentuan program jaminan sosial.

g. Memberikan informasi mengenai penyelenggaraan program jaminan sosial kepada peserta dan masyarakat.

Dalam melakukan pendaftaran peserta, Badan Penyelenggara Jaminan Sosial tidak berperan secara aktif untuk mencari anggota. Kepersertaan terhadap Badan Penyelenggara Jaminan Sosial Kesehatan khususnya merupakan inisiatif sendiri dari masyarakat yang belum terdaftar sebagai anggota Badan Penyelenggara Jaminan Sosial. Selanjutnya dalam hal memungut dan mengumpulkan iuran, Badan Penyelenggara Jaminan Sosial bekerjasama dengan beberapa bank nasional untuk menampung uang yang disetorkan oleh para anggoa. Iuran tersebut diberikan setiap bulan sekali untuk Badan Penyelenggara Jaminan
Sosial Kesehatan yang besarnya ditentukan berdasarkan kelas yang dipilih anggota. Selanjutnya apabila terjadi klaim dari anggota yang mengalami musibah, Badan Penyelenggara Jaminan Sosial melakukan tindak lanjut terhadap kasus tersebut.

Dalam melaksanakan fungsi,
tugas dan kewajibannya, Badan Penyelenggara Jaminan Sosial memiliki kewenangan atribusi (kewenangan yang berasal dari undang-undang). Kewenangan yang dimiliki oleh Badan Penyelenggara Jaminan Sosial dapat dilihat dalam Pasal 11 Undang-Undang Nomor 24 Tahun 2011. Dalam pasal tersebut, Badan Penyelenggara Jaminan Sosial memiliki wewenang untuk:

a. Menagih pembayaran iuran. Maksud dari menagih iuran di sini adalah meminta pembayaran dala hal terajdi penunggakan, kemacetan, atau kekurangan pembayaran iuran.

b. Menempatkan dana jaminan sosial untuk investasi jangka pendek dan jangka panjang dengan mempertimbangkan aspek likuiditas, solvabilitas, kehati-hatian, keamanan dana dan hasil yang memadai.

c. Melakukan pengawasan dan pemeriksaan atas kepatuhan peserta dan pemberi kerja dalam memenuhi kewajibannya sesuai dengan ketentuan peraturan perundang-undangan jaminan sosial nasional.

d. Membuat kesepakatan dengan fasilitas kesehatan mengenai besar pembayaran fasilitas kesehatan yang mengacu pada standar tarif yang ditetapkan 
pemerintah. Pemerintah akan menetapkan standar tarif setelah mendapatkan masukan dari BPJS bersama dengan asosiasi fasilitas kesehatan, baik tingkat nasional maupun tingkat daerah. Besaran tarif di suatu wilayah tertentu dapat berbeda dengan tarif wilayah lainnya sesuai dengan tingkat kemahalan harga setempat, sehingga diperoleh pembayaran fasilitas kesehatan yang efektif dan efisien.

e. Membuat atau menghentikan kontrak kerja dengan fasilitas kesehatan.

f. Mengenakan sanksi administratif kepada peserta atau pemberi kerja yang tidak memenuhi kewajibannya.

g. Melaporkan pemberi kerja kepada instansi yang berwenang mengenai ketidakpatuhannya dalam membayar iuran atau dalam memenuhi kewajiban lain sesuai dengan ketentuan perundang-undangan. Yang dimaksud dengan kewajiban lain antara lain kewajiban mendaftarkan diri dan pekerjanya sebagai peserta, melaporkan dana kepesertaan termasuk perubahan gaji atau upah, jumlah pekerja dan keluarganya, alamat pekerja, serta status pekerja.

h. Melakukan kerja sama dengan pihak lain dalam rangka penyelenggaraan jaminan sosial. Kerja sama dengan pihak lain terkait dengan pemungutan dan pengumpulan iuran dari peserta dan pemberi kerja serta penerimaan bantuan iuran dilakukan dengan instansi pemerintah dan pemerintah daerah, badan usaha milik negara dan badan usaha milik daerah.

Badan Penyelenggara Jaminan Sosial sebagai badan hukum publik memiliki hak dan kewajiban yang harus dipenuhi. Hak dan kewajiban Badan Penyelenggara Jaminan Sosial sendiri dapat ditemukan dalam Pasal 12 dan 13 Undang-Undang Nomor 24 Tahun 2011. Pasal 12 menyebutkan bahwa Badan Penyelenggara Jaminan Sosial berhak untuk :

a. Memperoleh dana operasional untuk penyelenggaraan program yang bersumber dari dana jaminan sosial dan/atau sumber lainnya sesuai dengan ketentuan perundnag-undanga. Dana operasional adalah bagian dari akumulasi iuran jaminan sosial dan hasil pengembangannya yang dapat digunakan Badan Penyelenggara Jaminan Sosial untuk membiayai kegiatan operasional penyelenggaraan program jaminan sosial.

b. Memperoleh hasil monitoring dan evaluasi penyelenggaraan program Jaminan Sosial dari DSJN setiap 6 bulan.

Selanjutnya dalam Pasal 13 menyebutkan bahwa Badan Penyelenggara Jaminan Sosial memiliki kewajiban untuk :

a. Memberikan nomor identitas tunggal kepada peserta. Yang dimaksud dengan nomor identitas tunggal adalah nomor yang diberikan secara khusus oleh Badan Penyelenggara 
Jaminan Sosial kepada setiap peserta untuk menjamin tertib administrasi atas hak dan kewajiban setiap peserta. Nomor identitas tunggal $b$ erlaku untuk semua jenis program jaminan sosial.

b. Mengembangkan aset dana jaminan sosial dan aset Badan Penyelenggara Jaminan Sosial untuk sebesar-besarnya kepentingan peserta.

c. Memberikan informasi melalui media massa cetak dan elektronik mengenai kinerja, kondisi keuangan, serta kekayaan dan hasil pengembangannya. Informasi mengenai kinerja dan kondisi keuangan

Badan Penyelenggara Jaminan Sosial mencakup informasi mengenai jumlah aset dan liabilitas, penerimaan dan pengeluaran untuk setiap Dana Jaminan Sosial dan/atau jumlah aset dan liabilitas, penerimaan dan pengeluaran Badan Penyelenggara Jaminan Sosial.

d. Memberikan manfaat kepada seluruh peserta sesuai dengan Undang-Undang tentang Sistem Jaminan Sosial Nasional.

e. Memberikan informasi kepada peserta mengenai hak dan kewajiban untuk mengikuti ketentuan yang berlaku.

f. Memberikan informasi kepada peserta mengenai prosedur memperoleh hak dan memenuhi kewajibannya.

g. Memberikan informasi kepada peserta mengenai saldo jaminan hari tua dan pengembangannya 1 kali dalam 1 tahun.

h. Memberikan informasi kepada peserta mengenai besar hak pensiun 1 kali dalam 1 tahun.

i. Membentuk cadangan teknis sesuai dengan standar praktik aktuaria yang lazim dan berlaku umum.

j. Melakukan pembukuan sesuai dengan standar akuntansi yang berlaku dalam penyelenggaraan Jaminan Sosial.

k. Melaporkan pelaksanaan setiap program, termasuk kondisi keuangan, secara berkala 6 bulan sekali kepada Presiden dengan tembusan kepada DJSN.

\section{Kepesertaan Badan Penyelenggara} Jaminan Sosial dan Pembayaran Iuran

Hal yang tak bisa lepas dari adanya perusahaan asuransi adalah kepesertaan. Dalam hal ini peserta lah yang menjadi sumber dana dalam operasional perusahaan selain dana yang berasal dari hal lain. Peserta dar BPJS sendiri tidak terbatas usia dan golongan masyarakat tertentu. Semua warga dapat menjadi peserta Badan Penyelenggara Jaminan Sosial bahkan wajib bagi yang memenuhi syarat tertentu.

Kepesertaan Badan Penyelenggara Jaminan Sosial adalah wajib bagi setiap orang, termasuk orang asing yang bekerja paling singkat 6 bulan di Indonesia. Pasal 15 UndangUndang tentang Badan Penyelenggara Jaminan Sosial menyebutkan bahwa pemberi kerja secara bertahap wajib mendaftarkan dirinya dan pekerjanya sebagai peserta kepada Badan 
Penyelenggara Jaminan Sosial sesuai dengan program Jaminan Sosial yang diikuti. Program jaminan sosial tersebut adalah jaminan kesehatan, jaminan kecelakaan kerja, jaminan hari tua, jaminan pensiun atau jaminan kematian. Pemberi kerja dalam hal ini wajib melakukan pendaftaran dengan memberikan data dirinya dari pekerjanya berikut anggota keluarganya secara lengkap dan benar kepada Badan Penyelenggara Jaminan Sosial. Selanjutnya mengenai penahapan tersebut akan diatur dalam Peraturan Presiden. Yang dimaksud dalam Peraturan Presiden adalah penahapan yang didasarkan antara lain pada jumlah pekerja, jenis usaha dan/atau skala usaha. Penahapan yang akan diatur tersebut tidak boleh mengurangi manfaat yang sudah menjadi hak peserta dan kewajiban pemberi kerja untuk mengikuti program Jaminan Sosial.

Selain itu, setiap orang, selan pemberi kerja, pekerja dan penerima bantuan iuran, yang memenuhi persyaratan kepesertaan dalam program Jaminan Sosial wajib mendaftarkan dirinya dan anggota keluarganya sebagai peserta Badan Penyelenggara Jaminan Sosial, sesuai dengan program Jaminan Sosial yang diikuti. Setelah itu, setiap orang tersebut wajib memberikan data mengenai dirinya dan anggota keluarganya secara lengkap dan benar kepada Badan Penyelenggara Jaminan Sosial. Apabila pemberi kerja selain penyelenggara negara dan setiap orang yang tidak melaksanakan ketentuan pendaftaran kepesertaan akan dikenai sanksai administratif. Sanksi administratif dapat berupa teguran tertulis, denda dan/atau tidak mendapatkan pelayanan publik tertentu.
Pelayanan publik tertentu tersebut contohnya adalah pemrosesan izin usaha, izin mendirikan bangunan, bukti kepemilikan hak tanah dan bangunan. Pengenaan sanksi tersebut dilakukan oleh Badan Penyelenggara Jaminan Sosial terhadap sanksi berupa teguran tertulis dan denda. Sedangkan untuk sanksi tidak mendapatkan pelayanan publik tertentu dilakukan oleh pemerintah atau pemerintah daerah atas permintaan Badan Penyelenggara Jaminan Sosial.

Pemerintah sesuai dengan Pasal 18 Undang-Undang Nomor 24 Tahun 2011 mendaftarkan penerima bantuan iuran dan anggota keluarganya sebagai peserta Badan Penyelenggara Jaminan Sosial. Penerima bantuan iuran tersebut wajib memberikan dana mengenai diri sendiri dan anggota keluarganya secara lengkap dan benar kepada pemerintah untuk disampaikan kepada Badan Penyelenggara Jaminan Sosial.

$$
\text { Iuran wajib dipungut oleh }
$$
pemberi kerja yang menjadi beban peserta dari pekerjanya dan menyetorkanya kepada Badan Penyelenggara Jaminan Sosial. Pemberi kerja membayar dan menyetor iuran yang menjadi tanggung jawabnya kepada Badan Penyelenggara Jaminan Sosial. Selanjutnya, peserta yang bukan pekerja dan bukan penerima bantuan iuran wajib membayar dan menyetor iuran yang menjadi tanggung jawabnya kepada Badan Penyelenggara Jaminan Sosial. Dalam hal ini, untuk penerima bantuan iuran dibayar dan disetor pemerintah kepada Badan Penyelenggara Jaminan Sosial.

\section{PENUTUP}

Berdasarkan ketentuan Pasal 12 Undang-Undang Nomor 24 Tahun 2011 
menyebutkan bahwa Badan

Penyelenggara Jaminan Sosial berhak untuk :

a. $\mathrm{M}$ operasional untuk penyelenggaraan program yang bersumber dari dana jaminan sosial dan/atau sumber lainnya sesuai dengan ketentuan perundnagundanga. Dana operasional adalah bagian dari akumulasi iuran jaminan sosial dan hasil pengembangannya yang dapat digunakan Badan Penyelenggara Jaminan Sosial untuk membiayai kegiatan operasional penyelenggaraan program jaminan sosial.

b. Memperoleh hasil monitoring dan evaluasi penyelenggaraan program Jaminan Sosial dari DSJN setiap 6 bulan.

Selanjutnya dalam Pasal 13 menyebutkan bahwa Badan Penyelenggara Jaminan Sosial memiliki kewajiban untuk :

a. Memberikan nomor identitas tunggal kepada peserta. Yang dimaksud dengan nomor identitas tunggal adalah nomor yang diberikan secara khusus oleh Badan Penyelenggara Jaminan Sosial kepada setiap peserta untuk menjamin tertib administrasi atas hak dan kewajiban setiap peserta. Nomor identitas tunggal berlaku untuk semua jenis program jaminan sosial.

b. Mengembangkan aset dana jaminan sosial dan aset Badan Penyelenggara Jaminan Sosial untuk sebesar-besarnya kepentingan peserta.

c. Memberikan informasi melalui media massa cetak dan elektronik mengenai kinerja, kondisi keuangan, serta kekayaan dan hasil pengembangannya. Informasi mengenai kinerja dan kondisi keuangan Badan Penyelenggara Jaminan Sosial mencakup informasi mengenai jumlah aset dan liabilitas, penerimaan dan pengeluaran untuk setiap Dana Jaminan Sosial dan/atau jumlah aset dan liabilitas, penerimaan dan pengeluaran Badan Penyelenggara Jaminan Sosial.

d. Memberikan manfaat kepada seluruh peserta sesuai dengan Undang-Undang tentang Sistem Jaminan Sosial Nasional.

e. Memberikan informasi kepada peserta mengenai hak dan kewajiban untuk mengikuti ketentuan yang berlaku.

f. Memberikan informasi kepada peserta mengenai prosedur memperoleh hak dan memenuhi kewajibannya.

g. Memberikan informasi kepada peserta mengenai saldo jaminan hari tua dan pengembangannya 1 kali dalam 1 tahun.

h. Memberikan informasi kepada peserta mengenai besar hak pensiun 1 kali dalam 1 tahun.

i. Membentuk cadangan teknis sesuai dengan standar praktik aktuaria yang lazim dan berlaku umum.

j. Melakukan pembukuan sesuai dengan standar akuntansi yang berlaku dalam penyelenggaraan Jaminan Sosial. 
Marsidah, Tinjauan Yuridis Tentang Pelaksanaan Hak Dan Kewajiban Badan Penyelenggaraan Jaminan Sosial Menurut Undang-Undang Nomor 24 Tahun 2011, halaman 193-202

k. Melaporkan pelaksanaan setiap program, termasuk kondisi keuangan, secara berkala 6 bulan sekali kepada Presiden dengan tembusan kepada DJSN.

\section{DAFTAR PUSTAKA}

\section{Buku-Buku}

Abdulkadir Muhammad, Pengantar Hukum Asuransi, PT. Citra Aditya Bakti, Bandung, 1994.

Abassalim, Dasar-Dasar Asuransi, Tarsito, Bandung, 1985.

Anggar Sigit Pramukti dan Andre Budiman Panjaitan, Pokok-Pokok Hukum Asuransi, Pustaka Yustisia, Yogyakarta, 2016.

Ronny Hanintijo Soemitro, Metode Penelitian Hukum dan Juru Metri, Ghalia Indonesia, Jakarta, 1998.

Sri Rezeki Hartono, Hukum Asuransi dan Perusahaan Asuransi, Sinar Grafika, Jakarta, 2001.

\section{Perundangan-Undangan}

Undang-Undang Dasar 1945.

Kitab Undang-Undang Hukum Perdata.

Undang-Undang Nomor 2 Tahun 1992 Tentang Usaha Perasuransian.

Undang-Undang Nomor 24 Tahun 2011

Tentang Badan Penyelenggara Jaminan Sosial (BPJS).

Peraturan Pemerintah Nomor 14 Tahun 1993. 